\title{
The Effect of Camel Ratio in Predicting Financial Distress Conditions in Banking Companies Registered in Indonesia Stock Exchange (BEI)
}

\author{
Yuhasril, Yuhasril Tri Wahyono Sumiyarsih, Sumiyarsih. Rina Dwiarti. \\ Trisakti School of Management
}

\begin{abstract}
This research was conducted to analyze the effect of Capital Adequacy Ratio (CAR), Non Performing Loans (NPL), Net Interest Margin (NIM), Operational Costs Operating Income (BOPO), and Loan to Deposit Ratio (LDR) on Financial Distress. The banking sector listed on the Indonesia Stock Exchange (IDX) for the 2014-2017 period was chosen as the population used in this study. The sampling technique used is probability sampling. The number of samples used were 22 banks listed on the Indonesia Stock Exchange (IDX). The analysis technique used is panel data regression. The results of this study indicate that the Capital Adequacy Ratio (CAR), Non Performing Loans (NPL), Net Interest Margin (NIM), Operational Costs Operating Income (BOPO), and Loan to Deposit Ratio (LDR) simultaneously have a significant effect on Financial Distress . Based on partial testing, Capital Adequacy Ratio (CAR), Net Interest Margin (NIM), Loan to Deposit Ratio (LDR) and Operational Costs Operating Income (BOPO) have an effect on Financial Distress while Non Performing Loans (NPL) have no effect on Financial Distress .
\end{abstract}

Keywords: Financial Distress, CAR, NPL, NIM, BOPO, and LDR.

DOI: $10.7176 / \mathrm{EJBM} / 12-18-10$

Publication date:June 30th 2020

\section{PRELIMINARY}

Banking health and stability will greatly affect the ups and downs of an economy. A healthy bank is a necessity for an economy that wants to grow and develop properly. In the modern world almost all business sectors really need banks as partners in conducting financial transactions. Given the magnitude of the influence of banks on a country's economy does not mean banks have no obstacles or problems. One of the problems faced by banks is the problem of poor financial management.

In the current era of globalization, economic conditions undergo a lot of change and become increasingly uncertain. This has affected the company's performance so that many companies experience financial distress due to poor financial management. Financial management in the company must be properly considered so that the company's survival can be maintained in the future.

Seeing the comparison of financial ratios can help to know the assessment of financial distress indicators that lead to bankruptcy for a company. Bankruptcy of a company can be seen and measured through financial statements.

Measures to assess bank financial performance have been determined by BI through Bank Indonesia Board of Directors Decree No.30 / 12 / KEP / DIR dated April 30, 1997 as amended by Bank Indonesia Board of Directors Decree No.30 / 277 / KEP / DIR dated 19 March 1998 concerning Procedures for Rating of Commercial Banks.

According to BI regulation No.6 / 10 / PBI / 2004 one of the tools to measure bank health there are 5 aspects, namely Capital, Assets, Management, Earning, and Liquidity. Capital aspects (capital) can be assessed through Capital Adequacy Ratio (CAR), Assets aspects are assessed with Non Performing Loans (NPL), Management aspects are valued by Net Interest Margin (NIM), Earning aspects include BOPO, and Liquidity aspects include Loan to Deposit Ratio (LDR).

The following is a table of developments in Capital Adequacy Ratio (CAR), Non Performing Loans (NPL), Net Interest Margin (NIM), Operational Operating Income Costs (BOPO), and Loan to Deposit Ratio (LDR) in conventional banks in 2014-2017.

\section{RESEARCH PURPOSES.}

The purpose of this study is to determine and analyze the effect of Capital Adequacy Ratio (CAR), Non Performing Loans (NPL), Net Interest Margin (NIM), Operational Income Operating Costs (BOPO), and Loan to Deposit Ratio (LDR) on Financial Distress in banks listed on the Indonesia Stock Exchange (IDX) for the 2014-2017 period.

\section{LITERATURE REVIEW.}

Signaling Theory is used to explain that financial statements are used to give positive signals (good news) and negative signals (bad news) to the wearer. According to Stephen A. Ross, (1997) when a company experiences 
financial distress, the company has bad news that shows a negative signal for investors so that this can affect the disclosure of management in making disclosure, whereas if the company is financially healthy it means the company has good news for investors so this will affect the management in providing company information, management is interested in conveying information that can increase the company's credibility and success even though the information is not required.

Signaling theory in this study emphasizes the importance of information released by the company on financial distress. If the financial distress condition is known in advance, the company is expected to take action to improve the situation so that the company will not experience difficulties or liquidity.

Financial distress is a condition where the company is facing financial difficulties, namely the company's operating cash flow is unable to pay off current obligations (for example interest expense) and the company is forced to make corrective actions to avoid the threat of bankruptcy / liquidation.

According to Wongsosudono and Chrissa (2013) "Financial difficulties can be interpreted as the inability of companies to pay their financial obligations when due which cause bankruptcy of the company".

According to Fahmi (2012), "the cause of financial distress is starting from the company's inability to fulfill its obligations, especially short-term obligations including liquidity obligations and also included obligations in the solvency category".

Indicators in Predicting Financial Distress

Companies that experience financial difficulties through several stages, there are always indications that can be used as initial predictions. According to Munawir (2015) there are several indicators or sources of information about possible financial difficulties, namely:

1. Analysis of cash flow statements for the present and future periods.

2. Analysis of corporate strategy by considering the potential of the competitor companies or institutions concerned with the relative cost structure, expansion or expansion in the industry, management's ability to control costs and quality of management.

3. Analysis of the company's financial statements with a comparison technique with several companies that can be focused on a single financial variable (univariate analysis) or with various combinations of financial variables (multivariate analysis).

\section{HYPOTHESIS.}

Effect of Capital Adequacy Ratio (CAR) on Financial Distress.

$\mathrm{H}_{1}=$ Capital Adequacy Ratio (CAR) effect on Financial Distress.

The Effect of Non Performing Loans (NPL) on Financial Distress.

$\mathrm{H}_{2}=$ Non Performing Loan (NPL) effect on Financial Distress.

Effect of Net Interest Margin (NIM) on Financial Distress.

$\mathrm{H}_{3}=$ Net Interest Margin (NIM) effect on Financial Distress.

Effect of Operating Costs and Operating Income (BOPO) on Financial Distress.

$\mathrm{H}_{4}=$ Operating Costs Operating Income (BOPO) affects Financial Distress.

Effect of Loan to Deposit Ratio (LDR) on Financial Distress.

$\mathrm{H}_{5}=$ Loan to Deposit Ratio (LDR) effect on Financial Distress.

\section{RESEARCH METHODS.}

Operationalization of Variables.

\section{Independent Variable}

The independent variable used in this study is the CAMEL ratiowhich is included in the CAMEL ratio in this study are as follows:

Capital Adequacy Ratio (CAR)

It is a ratio that shows how much the total assets of banks that contain risks (credit, investments, securities, bills) are financed from their own capital in addition to obtaining funds from sources outside the bank (Almilia and Herdiningtyas, 2005).

\begin{tabular}{|c|c|}
\hline \multirow[b]{2}{*}{$\mathrm{CAR}=$} & Bank Capital \\
\hline & $\begin{array}{l}\text { Risk weighted assets. } \\
\text { Non-performing loans x } 100 \% \text {. }\end{array}$ \\
\hline $\mathrm{NPL}=$ & $\begin{array}{l}\text { Total Credit. } \\
\text { Net interest income x } 100 \% \text {. }\end{array}$ \\
\hline $\mathrm{NIM}=$ & $\begin{array}{l}\text { Productive Assets. } \\
\text { Operational expenses x } 100 \% \text {. }\end{array}$ \\
\hline $\mathrm{BOPO}=$ & $\begin{array}{l}\text { Operating income } \\
\text { Total Credit }\end{array}$ \\
\hline DR & Total third party fur \\
\hline
\end{tabular}




\section{Dependent Variable.}

The dependent variable used in this study is financial distress.

0 for non-performing banks (score $>2.6$ ) and 1 for non-performing banks (score $<1.1-2.6$ ).

\section{ANALYSIS METHOD.}

\section{Panel Data Regression Model Estimation Method.}

1. Common Effect (pooled least square)

Here are the Common Effect models:

Information :

$$
Y=\alpha+\beta 1_{i t}+\beta 2_{i t}+\beta 3_{i t}+\beta 4_{i t}+\beta 5_{i t}+\varepsilon
$$

$\mathrm{Y}=$ Financial Distress.

$\alpha=$ Constant

$\beta 1=$ Capital Adequacy Ratio (CAR).

$\beta 2=$ Net Interest Margin (NIM).

$\beta 3=$ Non Performing Loans (NPL).

$\beta 4=$ Operational Costs Operating Income (BOPO).

$\beta 5=$ Loan to Deposit Ratio (LDR).

$\mathrm{i}=$ company.

$\mathrm{t}=$ year.

$\varepsilon=$ Error.

2. Fixed Effect (FE)

Following is the Fixed Effect modeling:

$$
Y=a_{1}+a_{2} D_{2 i}+a_{3} D_{3 i}+\cdots+a_{6} D_{6 i}+\beta 1_{i t}+\beta 2_{i t}+\beta 3_{i t}+u_{i t}
$$

Where D_2i $=1$ dummy for company 2,0 if not; D_3i $=1$ dummy for company 3,0 if not; etc.

3. Random Effect (RE)

Here is the Random Effect modeling:

Where :

$$
\mathrm{Y}=\alpha+\beta 1_{\mathrm{it}}+\beta 2_{\mathrm{it}}+\beta 3_{\mathrm{it}}+\beta 4_{i t}+\beta 5_{\mathrm{it}}+\omega_{\mathrm{it}}
$$

$\omega \_$it $+\varepsilon \_$it + u_it

$\omega$ it is a combined error term consisting of two components: $\varepsilon$ it, which is a cross-section or individual-specific error component, and $u_{\text {_ }}$ it, which is a combined time-series and cross section error component.

\section{RESULTS AND DISCUSSION}

Data Overview

In this study, the population used is the banking companies listed on the Indonesia Stock Exchange (IDX) for the 2014-2017 period. There are 43 banking companies listed on the Indonesia Stock Exchange in the 2014-2017 period. From the results of the probability sampling method used, 22 samples were obtained for 4 years, so we obtained 88 research data.

\begin{tabular}{|c|c|c|c|c|c|c|}
\hline & $\mathrm{FD}$ & CAR & NPL & NIM & BOPO & LDR \\
\hline Mean & 0.990084 & 19.01352 & 2.547045 & 5.515795 & 82.63068 & 86.28216 \\
\hline Median & 0.928000 & 18.56500 & 2.475000 & 5.155000 & 84.31500 & 87.69500 \\
\hline Maximum & 2.129700 & 29.58000 & 8.540000 & 11.98000 & 99.04000 & 111.0700 \\
\hline Minimum & -0.001900 & 10.44000 & 0.250000 & 1.530000 & 56.04000 & 50.61000 \\
\hline Std. Dev. & 0.395859 & 3.703103 & 1.296555 & 1.931360 & 9.434636 & 12.64646 \\
\hline Skewness & 0.194005 & 0.265742 & 1.332500 & 1.126950 & -0.805572 & -0.756984 \\
\hline Kurtosis & 2.946542 & 2.864959 & 7.298564 & 5.627432 & 3.230060 & 3.723520 \\
\hline Jarque-Bera & 0.562504 & 1.102609 & 93.79287 & 43.93936 & 9.711946 & 10.32379 \\
\hline Probability & 0.754838 & 0.576198 & 0.000000 & 0.000000 & 0.007782 & 0.005731 \\
\hline Sum & 87.12740 & 1673.190 & 224.1400 & 485.3900 & 7271.500 & 7592.830 \\
\hline Sum Sq. Dev. & 13.63326 & 1193.029 & 146.2518 & 324.5231 & 7744.074 & 13914.16 \\
\hline Observations & 88 & 88 & 88 & 88 & 88 & 88 \\
\hline
\end{tabular}

TABLE 1

DESCRIPTIVE STATISTIC TEST RESULTS.

1. Financial Distress

Financial Distress with the highest value of 2.129700 is found in Bank Danamon Indonesia Tbk in 2017 while Financial Distress with the lowest value of -0.001900 is found in Bank Bukopin Tbk in 2017. It can be seen that the standard deviation value in Financial Distress is 0.395859 smaller than the mean value of 0.990084 where it shows quite good results because the standard deviation reflects the high deviation.Financial Distress.

2. Capital Adequacy Ratio (CAR) 
Capital Adequacy Ratio (CAR) with the highest value of 29.58000 is in Bank Rakyat Indonesia Agro Niaga Tbk in 2017 while the lowest value of 10.44000 is in Bank Mayapada International Tbk in 2014. It appears that the standard deviation value of the Capital Adequacy Ratio (CAR) is 3.703103 more than small compared to the mean value of 19.01352 where it shows pretty good results because the standard deviation reflects the high deviation 3. Non Performing Loans (NPL)

Non Performing Loans (NPLs) with the highest value of 8.540000 are found in Bank Bukopin Tbk in 2017 while the lowest values of 0.250000 are found in Bank Bumi Arta Tbk in 2014. It is seen that the standard deviation value on Non Performing Loans (NPLs) is 1.296555 smaller than with a mean value of 2.547045 which shows pretty good results because the standard deviation reflects the high deviation.

4. Net Interest Margin (NIM)

Net Interest Margin (NIM) with the highest value of 11.98000 is in the National Savings Retirement Bank in 2016 while the lowest value of 1.530000 is in Bank Victoria International Tbk in 2016. It can be seen that the standard deviation of the Net Interest Margin (NIM) is 1.931360 more small compared to the mean value of 5.515795 where it shows pretty good results because the standard deviation reflects the high deviation. 5. Operational Costs Operating Income (BOPO)

Operational Costs Operating Income (BOPO) with the highest value of 99.04000 is found in Bank Bukopin Tbk in 2017 while the lowest value of 56.04000 is found in the Bank of Brothers 1906 Tbk in 2014. It can be seen that the standard deviation value in Operational Costs (BOPO) is 9,434636 smaller than the mean value of 82.63068 where it shows a pretty good result because the standard deviation reflects the high deviation.

6. . Loan to Deposit Ratio (LDR)

Loan to Deposit Ratio (LDR) with the highest value of 111,0700 is found in the Bank of Brothers 1906 Tbk in 2017 while the lowest value of 50.61000 is found in Bank Capital Indonesia Tbk in 2017. It can be seen that the standard deviation value in the Loan to Deposit Ratio (LDR) is 12.64646 is smaller than the mean value of 86.28216 which shows quite good results because the standard deviation reflects the high deviation.

Panel Data Regression Analysis Results.

\section{Random Effect Model.}

TABLE 2

\begin{tabular}{|c|c|c|c|c|}
\hline \# & RAND & OMEFFECT & IODEL. & \\
\hline \multirow{2}{*}{\multicolumn{5}{|c|}{$\begin{array}{l}\text { Dependent Variable: FINANCIAL_DISTRESS } \\
\text { Method: Panel EGLS (Cross-section random effects) }\end{array}$}} \\
\hline \multirow{2}{*}{\multicolumn{5}{|c|}{$\begin{array}{l}\text { Method: Panel EGLS (Cross-section random effects) } \\
\text { Date: } 07 / 05 / 19 \text { Time: } 00-53\end{array}$}} \\
\hline & & & & \\
\hline \multicolumn{3}{|c|}{ Sample: 20142017} & | & \\
\hline \multicolumn{5}{|l|}{ Periods included: 4} \\
\hline \multicolumn{5}{|c|}{ Cross-sections included: 22} \\
\hline \multicolumn{5}{|c|}{ Total panel (balanced) observations: 88} \\
\hline \multicolumn{5}{|c|}{ Swamy and Arora estimator of component variances } \\
\hline Variable & Coefficient & Std. Error & t-Statistic & Prob. \\
\hline $\mathrm{C}$ & 0.832573 & 0.347786 & 2.384057 & 0.0188 \\
\hline CAR & 0.021084 & 0.004701 & 4.484761 & 0.0000 \\
\hline NFL & 0.008693 & 0.012902 & 0.518730 & 0.8053 \\
\hline NIM & 0.063387 & 0.018998 & 3.336502 & 0.0013 \\
\hline BOPO & -0.016401 & 0.002846 & -5.762854 & 0.0000 \\
\hline \multirow[t]{3}{*}{ LDR } & 0.008837 & 0.002725 & 3.169758 & 0.0021 \\
\hline & \multicolumn{4}{|c|}{ Effects Specification } \\
\hline & & & S.D. & Rho \\
\hline \multirow{2}{*}{\multicolumn{3}{|c|}{$\begin{array}{l}\text { Cross-section random } \\
\text { Idiosyncratic random }\end{array}$}} & 0.224600 & 0.8371 \\
\hline & & & 0.099068 & 0.1628 \\
\hline \multicolumn{5}{|c|}{ Weighted Statistics } \\
\hline R-squared & 0.538167 & \multirow{2}{*}{\multicolumn{2}{|c|}{$\begin{array}{l}\text { Mean dependent var } \\
\text { S.D. dependent vir }\end{array}$}} & 0.213224 \\
\hline Adjusted R-squared & 0.507884 & & & 0.143108 \\
\hline S.E. of regression & 0.100392 & \multicolumn{2}{|c|}{ Sum squared resid } & 0.828442 \\
\hline F-statistic & 18.95752 & \multicolumn{2}{|c|}{ Durbin-Watson stat } & 1.489023 \\
\hline \multirow[t]{2}{*}{ Prob(F-statistic) } & 0.000000 & & & \\
\hline & \multicolumn{4}{|c|}{ Unweighted Statistics } \\
\hline R-squared & 0.822824 & Mesn depende & it var & 0.990084 \\
\hline Sum squared resid & 5.140770 & Durbin-Watson & & 0.239379 \\
\hline
\end{tabular}

Hypothesis Test Results

Determination Coefficient Test

It can be seen that the adjusted R-Square is 0.507884 or $50.7884 \%$. This shows that the Financial Distress variable can be explained by the CAR, NPL, NIM, BOPO, and LDR variables of 50.7884\% while the remaining $49.2116 \%$ is explained by other factors not examined in this study. Simultaneous Significance Test (Statistical Test F) 
Based on the results of testing the model using the Random Effect model that has been done, an F-statistic value of 18.95752 was obtained with an F-statistic probability of 0.000000 which is smaller than the significance level of $5 \%$. Because the probability value is smaller than $0.05, \mathrm{H}_{0}$ is rejected, and the independent variables in this study, namely CAR, NPL, NIM, BOPO and LDR together have a significant effect on the Financial Distress of banking companies listed on the Indonesia Stock Exchange (BEI) for the 2014 period -2017.

T Test Statistics and Discussion.

\section{a. Effect of CAR on Financial Distress.}

The coefficient value of the CAR variable that is equal to 0.021084 moves positively, the t-statistic value is 4.484761 with a probability of $0.0000<0.05$, then $\mathrm{Ha}$ is accepted. There is a significant influence between CAR variables on the Financial Distress of banking companies listed on the Indonesia Stock Exchange (IDX) for the 2014-2017 period. This means that the higher the CAR, the better the bank's ability to bear the risk of any credit / earning assets that are at risk and avoid the conditions of Financial Distress.

The results of this study are supported by Pratama research (2015) which states that CAR has a significant positive effect on the condition of Financial Distress and also research Almilia and Herdiningtyas (2005) which states that CAR has a significant effect on the condition of Financial Distress.

\section{b. Effect of NPLs on Financial Distress.}

The coefficient value of the NPL variable that is 0.006693 moves positively, the t-statistic value is 0.518730 with a probability of $0.6053>0.05$, then $\mathrm{H}_{0}$ is accepted. There is no influence between NPL variables on the Financial Distress of banking companies listed on the Indonesia Stock Exchange (IDX) for the 2014-2017 period. NPLs reflect credit risk. This means that the lower the NPL ratio, the lower the credit risk borne by the bank.

The results of this study are supported by the research of Almilia and Herdiningtyas (2005) which states that NPL has no significant positive effect on problematic conditions. Aji Nugroho's research (2011) also states that NPL has no significant positive effect on the condition of Financial Distress.

\section{c. Effect of NPLs on Financial Distress.}

The coefficient value of the NPL variable that is 0.006693 moves positively, the t-statistic value is 0.518730 with a probability of $0.6053>0.05$, then $\mathrm{H}_{0}$ is accepted. There is no influence between NPL variables on the Financial Distress of banking companies listed on the Indonesia Stock Exchange (IDX) for the 2014-2017 period. NPLs reflect credit risk. This means that the lower the NPL ratio, the lower the credit risk borne by the bank.

The results of this study are supported by the research of Almilia and Herdiningtyas (2005) which states that NPL has no significant positive effect on problematic conditions. Aji Nugroho's research (2011) also states that NPL has no significant positive effect on the condition of Financial Distress.

\section{d. Effect of NIMs on Financial Distress.}

The coefficient value of the NIM variable is 0.06693 , it moves positively, the t-statistic value is 3.336502 with a probability of $0.0013<0.05$, then Ha is accepted. There is a significant influence between the NIM variables on the Financial Distress of banking companies listed on the Indonesia Stock Exchange (IDX) for the 2014-2017 period. That is, the greater the NIM, the interest income on earning assets managed by the bank increases so that the possibility of a bank in problematic conditions is getting smaller.

The results of this study are supported by research by Dea Septian (2013) which states that NIM has a significant positive effect on the level of bank health.

\section{e. Effect of BOPO on Financial Distress}

The coefficient value of the BOPO variable is -0.016401 , it moves negative, the t-statistic value is $0-5.762654$ with a probability of $0.0000<0.05$, then $\mathrm{Ha}$ is accepted. There is a significant influence between BOPO variables on the Financial Distress of banking companies listed on the Indonesia Stock Exchange (IDX) for the 2014-2017 period. That is, the greater the value of the BOPO, it indicates that the bank's operational burden is greater than bank's income. Bank revenue that is far less than operating expenses will certainly provide a smaller profit. This shows that the increased value of BOPO will cause banks to be closer to the risk of Financial Distress.

The results of this study are supported by research Hutasoit and Mulyo (2016) which states that the BOPO has a negative effect on the risk of bankruptcy.

\section{f. Effect of LDR on Financial Distress}

The coefficient value of the LDR variable is 0.008637 , it moves positively, the t-statistic value is 3.169758 with a probability of $0.0021<0.05$, then Ha is accepted. There is a significant influence between the LDR variables on the Financial Distress of banking companies listed on the Indonesia Stock Exchange (IDX) for the 2014-2017 period. LDR is used to measure the amount of funds placed in the form of credit originating from funds collected by banks. This means that the amount of the LDR will affect the level of profitability of banks in getting interest from loans so that the greater the credit extended will increase bank income. The higher the level of the LDR ratio, the higher the potential for the bank to experience Financial Distress.

The results of this study are supported by research by Christiana Kurniasari (2013) which states that LDR has a significant effect on Financial Distress.

\section{CONCLUSIONS AND SUGGESTIONS}




\section{A. Conclusions}

This study aims to examine the effect of Capital Adequacy Ratio (CAR), Non Performing Loans (NPL), Net Interest Margin (NIM), Operational Income Operating Costs (BOPO), and Loan to Deposit Ratio (LDR) on Financial Distress of listed banking companies on the Indonesia Stock Exchange (IDX) for the 2014-2017 period. Based on the results of the analysis, the conclusions that can be drawn from this study are:

1. The analysis shows that CAR has a significant effect on the Financial Distress of banking companies listed on the Indonesia Stock Exchange (IDX) for the 2014-2017 period.

2. The analysis shows that NPL has no effect on the Financial Distress of banking companies listed on the Indonesia Stock Exchange (IDX) for the 2014-2017 period.

3. The analysis shows that NIM has a significant effect on the Financial Distress of banking companies listed on the Indonesia Stock Exchange (IDX) for the 2014-2017 period.

4. The analysis shows that BOPO has a significant effect on the Financial Distress of banking companies listed on the Indonesia Stock Exchange (IDX) for the 2014-2017 period.

5. The analysis shows that LDR has a significant effect on the Financial Distress of banking companies listed on the Indonesia Stock Exchange (IDX) for the 2014-2017 period.

\section{B. Suggestions}

After seeing the conclusions obtained from the data processing of banking companies listed on the Indonesia Stock Exchange (IDX), the following are suggestions from researchers aimed at companies, investors, and future researchers:

1. For Companies

This research can be used as reference material for banking companies to find out early whether the company is experiencing financial distress or not. In addition, companies should pay more attention to each ratio, such as the need to increase the Capital Adequacy Ratio (CAR) ratio each year, then the banking company should also reduce the Non Performing Loan (NPL) ratio and also the Operational Income Operational Cost (BOPO) ratio each year in order to avoid financial distress and not go bankrupt. Banking companies can also continuously improve their performance to avoid financial distress.

2. For Investors

This research can be used as information material for prospective investors who will invest in the banking sector to better know the condition of a banking company that will be used as a place to invest, in addition to this research it is also expected that potential investors can consider more in terms of investment decisions .

3. For Researchers

The next researcher is expected to increase the number of samples used, or add other variables used to see the effect on financial distress. Because there are many other ratios that affect the condition of financial distress in banking companies in Indonesia.

\section{BIBLIOGRAPHY.}

Agus Harjitno and Martono. 2010. Financial Management, Third Edition. Yogyakarta: Ekonisia.

Almila, Luciana Spica and Winny Herdiningtyas. 2005. Camel ratio to prediction analysis, problematic conditions in banking institutions in the 2000-2002 period. Indonesian Accounting and Auditing Journal (JAAI) Vol.7 No.2 December.

Argo, Asmoro. (2010). Analysis of the Effect of Financial Ratios on Prediction of Problematic Conditions in Banks (Case Study at the National Private Private Bank for the period 2004-2007), Accounting Department, Faculty of Economics, Diponegoro University, Semarang.

Bank Indonesia. 1998. Circular No. 30/277 / KEP / DIR March 19, 1998 concerning Procedures for Assessing Bank Health. Jakarta.

Bank Indonesia. 2004. Bank Indonesia Regulation No 6/10 / PBI / 2004 April 12, 2004 concerning the Bank's Health assessment System. Jakarta.

Bank Indonesia. 2004. Bank Indonesia Regulation No.6 / 10 / PBI / 2004 concerning financial performance evaluation. Jakarta.

Bank Indonesia. Decree of the Board of Directors of BI No.26 / 20 / KEP / DIR concerning the minimum capital requirement (KPMM). Jakarta.

Bank Indonesia. BI Circular Letter No.26 / 2 / BPPD concerning the obligation to provide minimum capital (CAR). Jakarta.

Darmawi. 2011. Banking Management. Jakarta: Earth Literacy.

Djalil, Rizal. 2014. Regional Financial Accountability, Post-Reform Implementation. Issue 1. Jakarta: Semester Rakyat Merdeka.

Fahmi, Irham. 2012. Analysis of Financial Statements. Bandung: CV Alfabeta.

Ghozali, I. 2011. Application of Multivariate Analysis with SPSS 19 program. Semarang: Diponegoro University 
Publisher Agency.

Ghozali, I. 2013. Application of Multivariate Analysis with the IBM SPSS Program. Semarang: Diponegoro University Publisher.

Ishmael. 2010. Banking Management from Theory to Application. Jakarta: Kencana Prenada Media Group.

Jensen and Meckling. 1976. The Theory of The Firm: Managerial Behavior, Agency Cost, and Ownership Structure. Journal of Financial and Economics, 3: 305-360.

Cashmere. 2008. Banking Management. 2008 Revised Edition. Jakarta: PT Raja Grafindo Persada.

Cashmere. 2012. Analysis of Financial Statements. Jakarta: PT Raja Grafindo Persada.

Kuncoro, Mudrajad \& Suhardjono, 2011, Banking Management. Yogyakarta: BPFE.

Munawir. 2010. Analysis of Financial Statements. Yogyakarta: Liberty Yogyakarta.

Riyadi, Slamet. 2006. Banking Assets and Liability Management. Faculty of Economics, University of Indonesia. Jakarta.

Rodoni, Ahmad \& Herni Ali. (2010). Financial management. First edition. Jakarta: Mitra Discourse Media.

Ross, Stephen A. 1997. "The Determination of Financial Structure: The Incen Signaling Approach". Bell Journal of Economics and Management Sciene 8, 23-40.

Santoso, Singgih. 2012. Parametric Statistics. Jakarta: PT Gramedia Pustaka Umum.

Sartono, Agus. 2010. Financial Management Theories and Applications. Fourth Edition. Yogyakarta: BPFE.

Sucipto. 2003. Financial Performance Rating. Medan: Journal of Accounting.

Sugiyono 2016. Management Research Methods. Bandung: Alfabeta.

Taswan 2010. Banking Management Concepts, Techniques, and Applications. Yogyakarta: UPP STIM YKPN.

Triandaru and Budisantoso. 2008. Banks and Other Financial Institutions. Jakarta: Salemba Empat.

Veithzal et al. 2013. Islamic Risk Management For Islamic Bank. Jakarta: PT Gramedia Pustaka Utama.

Wongsosudono, Corinna and Chrissa. 2013. Analysis of Financial Ratios to Predict Financial Distress in Financial Sector Companies Listed on the IDX. Thesis Published. Department of Accounting IBBI College of Economics.

Website:

https://finance.detik.com/2016/

http://sahamok..com/emiten/sektorfinance/sub-sektor-bank/

http://www.idx.co.id/ 